\title{
Pendampingan Penguasaan Table Manners Untuk Bisnis Bagi Karyawan BPR Mandiri
}

\author{
Nani Cahyani, Ratih Puspitasari, Rini Syarif \\ Program Studi Manajemen, Institut Bisnis dan Informatika Kesatuan \\ Bogor, Indonesia
}

E-Mail: nani.cahyani@ibik.ac.id

\begin{abstract}
ABSTRAK
Kegiatan makan bersama kolega dalam rangka berbisnis menjadi bagian yang seringkali tidak terpisahkan. Kegiatan yang sederhana ini memiliki dampak besar terhadap keberhasilan suatu kerjasama bisnis. Adat istiadat ketimuran menunjukkan bahwa menjamu makan rekan kerja atau kolega bisnis menjadi bagian yang penting untuk menjalin komunikasi yang hangat dan cair. Untuk itu menjadi penting bagi pelaku bisnis untuk menguasai konsep dan teknik table manner dengan benar. Tujuan diadakannya pelatihan Table Manners adalah untuk memberikan tutorial secara langsung mengenai bagaimana mengaplikasikan tata cara makan secara formal sesuai dengan kaidah table manners. Metode pelatihan melalui tutorial secara langsung, dimana seluruh partisipan diberikan jamuan makan siang mulai dari appetizer, soup, main course hingga dessert. Pada setiap course jamuan, diberikan pemaparan terkait food knowledge dan juga table manners. Penyampaian materi diberikan secara oral dengan bantuan power point pada layar televsi di dalam restoran. Melalui pelatihan ini, diharapkan partisipan dapat mengaplikasikan bagaimana berperilaku dan bersikap serta memahami tata cara dalam jamuan secara formal
\end{abstract}

Kata Kunci: bisnis, komunikasi bisnis, table manner, kolega bisnis

\section{PENDAHULUAN}

Table manners adalah aturan etika yang dipergunakan pada saat makan, yang mana memberikan petunjuk-petunjuk yang benar dalam penggunaan alat makan. Perbedaan budaya makan dapat membuat aturan tersebut berubah-ubah yang bertujuan menambah wawasan seseorang tentang etika budaya bangsa- bangsa lain," ungkap Tito Andika, F \& B Trainer Aston Rasuna Hotel, yang menjadi narasumber dalam pelatihan yang diadakan di Hotel Aston, Selasa (27/12). Masih banyak yang tidak begitu paham dengan etika jamuan makan resmi atau yang lebih dikenal dengan table manners. Etika tersebut merupakan warisan kebudayaan Eropa. Table manners sudah dilakukan oleh kalangan pejabat kerajaan di Prancis pada abad ke-17.

Saat ini, etika tersebut lebih sering dikenal orang-orang yang mempunyai kepentingan seperti para pengusaha, pejabat, orang penting, juru masak, dan lain- lain. Table manners digunakan para pengusaha ataupun pejabat untuk mempererat hubungan bisnis dan menjamin koleganya. Etika jamuan makan tersebut secara tidak langsung juga memberikan citra umum bagi latar belakang keluarga ataupun usaha dan bisnis. Etika pergaulan skala nasional maupun internasional tidak lepas dari tata cara jamuan atau "TABLE MANNERS". Etika makan atau Table manners adalah aturan yang harus dilakukan saat bersantap bersama di meja makan. Mempelajari etiket di meja makan bukan sekadar mengetahui tata krama saat makan atau menggunakan alat makan. Menguasai table manners juga merupakan bentuk citra diri, bahkan profesionalisme. Pemahaman yang baik seputar table manners bahkan memengaruhi kesuksesan karier atau bisnis. Meja makan adalah tempat terpenting dimana etiket ditonjolkan. Orang lain

Submitted: MEI 2020

Accepted: JUNI 2020

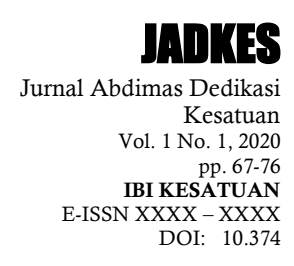


Kompetensi Komunikasi Bisnis Bagi Karyawan

$\underline{68}$

akan mengenali, melihat, dan menilai diri Anda dari profesionalisme yang ditunjukkan di meja makan. Inilah sebabnya kita perlu belajar table manners.

Bank Pekreditan Rakyat merupakan salah satu jenis bank yang dikenal melayani golongan usaha mikro, kecil dan menengah. Lokasi BPR biasanya dekat dengan tempat masyarakat yang membutuhkan sehingga BPR banyak dijumpai di setiap daerah yang tersebar di seluruh wilayah Indonesia. BPR merupakan lembaga perbankan resmi yang diatur berdasarkan pada Undang-Undang No. 7 Tahun 1992 tentang Perbankan dan sebagaimana telah disempurnakan dengan Undang-Undang No. 10 Tahun 1998. Pengertian BPR sesuai dengan UU tersebut adalah bank yang melaksanakan kegiatan usaha secara konvensional atau berdasarkan pada Prinsip Syariah yang dalam kegiatannya tidak memberikan jasa dalam lalu lintas pembayaran. Dengan jamuan makan yang baik, BPR juga bisa mendapatkan relasi bisnis yang baru sehingga bisnis yang dijalankan diharapkan akan terus berkembang dan mampu bersaing dengan baik.

Adapun manfaat yang dari penyelenggaraan Pelatihan Table Manners bagi BPR Mandiri, yakni :

1. Peserta pelatihan memahami pengertian dan manfaat mempelajari "Table Manners".

2. Peserta pelatihan diharapkan dapat membentuk perilaku yang sopan dan beretika sehingga akan mencerminkan diri kita dihadapan orang lain.

3. Untuk meningkatkan kepercayaan diri dihadapan orang lain.

\section{PELAKSANAAN KEGIATAN \\ Waktu Pelaksanaan}

Kegiatan pelatihan Table manners bagi BPR MANDIRI diselenggarakan dengan kerjasama antara LPPM STIE Kesatuan, BPR Mandiri dan Hotel Santika Bogor. Acara dilakukan selama 1 hari pada tanggal 12 April 2019 Tempat penyelenggaraan di Hotel Santika Bogor.

\section{Kerangka Pemecahan Masalah}

Permasalahan yang diangkat dalam kegiatan pengabdian pada masyarakat adalah memberikan pelatihan mengenai table manners bagi karyawan BPR MANDIRI. Kerangka pemecahan masalah dimaksud dilakukan dengan menerapkan langkah kerja dalam pengabdian pada masyarakat sebagai berikut:

1. Menetapkan jumlah peserta pelatihan yakni 10 orang karyawan BPR MANDIRI di wilayah kota Bogor.

2. Seluruh peserta mengikuti pelatihan di Hotel Santika Kota Bogor yang telah dilengkapi dengan sarana dan prasarana yang memadai.

3. Materi pelatihan yang diberikan meliputi :
a. Materi 1 : Memberikan pengetahuan tentang pengertian dan manfaat table manners.
b. Materi 2 : Tata cara table manners
c. Materi 3 : Etika Makan
d. Materi 4 : Etika Jamuan Makan Bisnis

Kerangka pikir untuk pemecahan masalah di atas dapat dijelaskan dalam bentuk matrik sebagai berikut :

\footnotetext{
JADKES

Jurnal Abdimas Dedikasi

Kesatuan

Vol. 1 No. 1, 2020

pp. $67-76$

IBI KESATUAN

E-ISSN XXXX - XXXX

DOI:
}

\begin{tabular}{|l|l|}
\hline \multicolumn{1}{|c|}{ Masalah } & \multicolumn{1}{|c|}{ Upaya Pemecahan Masalah } \\
\hline $\begin{array}{l}\text { Bagaimana memberikan wawasan } \\
\text { berupa pengertian dan manfaat } \\
\text { mempelajari table manners. }\end{array}$ & $\begin{array}{l}\text { Dilakukan dengan cara ceramah dan tanya } \\
\text { jawab. }\end{array}$ \\
\hline $\begin{array}{l}\text { Bagaimana memberikan pemahaman } \\
\text { kepada peserta pelatihan mengenai } \\
\text { tata cara table Manners }\end{array}$ & $\begin{array}{l}\text { Dilakukan dengan cara ceramah dan } \\
\text { tanya jawab serta memberikan contoh } \\
\text { mengenai tata cara table manners. }\end{array}$ \\
\hline $\begin{array}{l}\text { Bagaimana memberikan contoh etika } \\
\text { yang harus dilakukan dalam } \\
\text { perjamuan makan. }\end{array}$ & $\begin{array}{l}\text { Dilakukan dengan cara ceramah dan } \\
\text { tanya jawab serta praktek penggunaan alat } \\
\text { makan. }\end{array}$ \\
\hline
\end{tabular}




\begin{tabular}{l|l|}
$\begin{array}{l}\text { Bagaimana memberikan contoh etika } \\
\text { yang harus dilakukan dalam } \\
\text { perjamuan makan bisnis. }\end{array}$ & $\begin{array}{l}\text { Dilakukan dengan cara ceramah dan } \\
\text { tanya jawab serta praktek penggunaan alat } \\
\text { makan. }\end{array}$ \\
\hline
\end{tabular}

\section{Khalayak Sasaran Antara Yang Strategis}

Sasaran kegiatan ini adalah karyawan BPR MANDIRI di wilayah kota Bogor. Pertimbangan penetapan sasaran pelatihan Table manners adalah agar dapat digunakan para pengusaha ataupun pejabat untuk mempererat hubungan bisnis dan menjamin koleganya. Dengan jamuan makan yang baik, diharapkan BPR mampu mendapatkan relasi bisnis yang baru sehingga bisnis yang dijalankan diharapkan akan terus berkembang dan mampu bersaing dengan baik. Pertimbangan selanjutnya adalah bahwa STIE Kesatuan sebagai Perguruan Tinggi yang memiliki fungsi pengabdian kepada Masyarakat memiliki kewajiban untuk membantu BPR MANDIRI agar dapat mengembangkan usahanya ke arah yang lebih maju.

\section{Keterikatan}

Kegiatan pengabdian pada masyarakat ini diselenggarakan oleh STIE Kesatuan yang secara teknis dilakukan oleh Lembaga Penelitian dan Pengbdian kepada Masyarakat (LPPM) dengan dukungan sumber daya manusia yang memiliki latar belakang akademisi dan praktisi. Hal-hal yang berkaitan dengan sumber daya manusia serta sarana dan prasarana LPPM STIE Kesatuan dapat dijelaskan sebagai berikut :

a. Memiliki dosen yang profesional dan berpengalaman dalam menghasilkan berbagai jenis karya tulis ilmiah yang bermutu.

b. Memiliki dosen yang profesional dan berpengalaman dalam pelaksanaan kegiatan penataran dan pelatihan.

Adapun potensi yang dimiliki oleh karyawan BPR MANDIRI adalah keinginan yang kuat untuk mengetahui dan memahami manfaat pelatihan Table manners demi meningkatkan kepercayaan diri SDM dengan semangat kewirausahaan yang tinggi, termotivasi untuk mengembangkan usaha ke arah yang lebih maju.

\section{Metode Pelaksanaan}

Metode kegiatan ini berupa pelatihan Table manners kepada karyawan BPR MANDIRI di wilayah kota Bogor. Setelah pelatihan dilakukan, karyawan BPR MANDIRI diharapkan dapat memahami pentingnya kegiatan table manners, memiliki kepercayaan diri yang tinggi, khususnya dalam hal pertemuan bisnis demgam kolega di meja makan. Dengan jamuan makan yang baik, BPR juga diharapka mampu mendapatkan relasi bisnis yang baru sehingga bisnis yang dijalankan diharapkan akan terus berkembang dan mampu bersaing denganbaik.

Berikut disajikan tahapan pelatihan yang dilakukan :

1. Tahap Persiapan

Pada tahap persiapan hal yang dilakukan meliputi : Observasi calon peserta, Pemantapan dan penentuan lokasi dan sasaran, Penyusunan bahan/materi pelatihan : makalah dan modul untuk kegiatan pelatihan Table manners bagi BPR Mandiri.

2. Tahap Pelaksanaan Pelatihan

Pada tahap pelaksanaan ini pelatihan dilaksanakan dengan menyampaikan dan mempraktekkan materi: 1) pengetahuan tentang pengertian dan manfaat table manners, 2) Tata cara table manners, 3) Etika Makan dan 4) Etika Jamuan Makan Bisnis.

\section{Metode Pelatihan}

Metode kegiatan pelatihan dapat dijelaskan sebagai berikut :

a. Metode Ceramah. Metode ini digunakan untuk memberikan wawasan dan pengertian dan manfaat mempelajari table manners.

b. Metode Tanya Jawab. Metode ini digunakan untuk mengetahui hal-hal yang belum dipahami mengenai bagaimana tata cara table manners dan etika di meja makan maupun etika ketika makan.

c. Metode Praktek. Metode ini digunakan agar peserta pelatihan dapat memahami dan mempraktekkan bagaimana etika di meja makan, cara menggunakan peralatan

Kompetensi

Komunikasi Bisnis

Bagi Karyawan

\section{9}


Kompetensi

Komunikasi Bisnis

Bagi Karyawan

\section{0}

\section{JADKES}

Jurnal Abdimas Dedikasi

Kesatuan

Vol. 1 No. 1,2020

pp. $67-76$

Pp. KESATUAN

E-ISSN XXXX - XXXX

DOI: makan dan tata cara makan yang baik dan benar dalam suatu jamuan makan.

\section{HASIL DAN PEMBAHASAN \\ Hasil}

Program kegiatan pengabdian kepada masyarakat ini dilaksanakan bagi karyawan BPR MANDIRI di wilayah kota Bogor berupa pelatihan Table Manners pada tanggal 25 April 2019 Kegiatan pelatihan ini dilaksanakan dengan metode :

\section{Metode Ceramah}

Metode ini digunakan untuk memberikan wawasan dan pengertian dan manfaat mempelajari table manners.

2. Metode Tanya Jawab

Metode ini digunakan untuk mengetahui hal-hal yang belum dipahami mengenai bagaimana tata cara table manners dan etika di meja makan maupun etika ketika makan.

3. Metode Praktek

Metode ini digunakan agar peserta pelatihan dapat mememahami dan mempraktekkan bagaimana etika di meja makan, cara menggunakan peralatan makan dan tata cara makan yang baik dan benar dalam suatu jamuan makan.

Tahap pelaksanaan merupakan tahapan inti penyelenggaraan kegiatan pelatihan Table manners. Pada tahap ini kegiatan yang dilakukan sebanyak 3 sesi utama dan 1 sesi tambahan, yakni :

Sesi pertama. Pada sesi ini pembicara memberikan pengetahuan dan wawasan tentang pengertian dan manfaat table manners, sebagai berikut : Materi Sesi 1 tentang pengetahuan dasar konsep dan definisi Table manner disampaikan dengan mengungkapkan bahwa Tabel manners adalah aturan etika yang dipergunakan pada saat makan, yang mana memberikan petunjuk-petunjuk yang benar dalam penggunaan alat makan. Perbedaan budaya makan dapat membuat aturan tersebut berubah-ubah yang bertujuan menambah wawasan seseorang tentang etika budaya bangsa- bangsa lain. Beberapa orang mungkin bertanya-tanya, dari mana semua keelokan etika di atas meja ini bermula? Sekarang, mari kita pergi ke masa lalu sebentar untuk membahas secara singkat sejarah dari table manner di bawah ini. Abad ke-15 merupakan tahun-tahun di mana masyarakat Prancis baru bisa menyantap hidangan di atas meja mereka dengan sikap yang lebih elegan. Pada awalnya, masyarakat Kota Cahaya tersebut masih memiliki kebiasaan menyantap daging-daging di atas meja makan dengan menggunakan tangan yang kurang higienis. Tidak perlu waktu lama, Ratu Prancis, Catherine de' Medici, memiliki gagasan bermanfaat dimana ia berencana menyulap kebiasaan masyarakat Paris yang semula nampak tidak memiliki etiket makan yang baik.

Singkatnya, etiket table manner yang dikembangkan dimulai dari bagaimana penataan posisi peralatan makan dan minum, hingga elok budi penggunaan serbet mulut. Mengatur sikap diri yang benar selama menikmati hidangan pun tidak ketinggalan. Kemudian pada abad ke-18, istilah table manner mulai berkembang kepopulerannya di masyarakat Prancis. Penggunaan pisau di tangan kanan dan garpu di tangan kiri termasuk bagian dari lukisan sejarah tata cara makan yang berasal dari Prancis berkat Ratu de' Medici.

Etika Makan atau Table Manner adalah aturan yang harus dilakukan saat bersantap bersama di meja makan. Etika makan diperkenalkan oleh bangsa Eropa yang merupakan aturan standar terutama saat bersantap bersama-sama di sebuah acara resmi atau acara makan bersama di keluarga besar. Jika mampu menunjukkan sopan santun di meja makan, sebenarnya secara tidak langsung menunjukkan kualitas pergaulan, intelektualitas dan etika pergaulan seseorang. 
Dengan jamuan makan yang baik, diharapkan pengusaha mampu mendapatkan relasi bisnis yang baru sehingga bisnis yang dijalankan diharapkan akan terus berkembang dan mampu bersaing dengan baik.

Sesi kedua. Pada sesi ini pembicara memberikan pemahaman kepada peserta pelatihan mengenai tata cara table manners, sebagai berikut:

a) Alat Makan :

1. Sendok dan Garpu

Pegang sendok di tangan kanan dan garpu di tangan kiri. Makan dengan sendok dan garpu sangatlah mudah, sendok digunakan untuk mengambil makanan dan garpu dapat digunakan untuk menusuk makanan atau membantu mengunpulkan makanan di sendok, begitu mudah.

\section{1}

2. Pisau \& Garpu

Cara makan dengan pisau dan garpu tidaklah sulit, anda tetap memegang garpu ditangan kiri dan pisau ditangan kanan. Garpu digunakan untuk menusuk dan menahan makanan pada tempatnya selagi anda memotong makanan tersebut menjadi potongan yang lebih kecil dengan menggunakan pisau.

3. Sumpit

Makan dengan memakai sumpit juga bukan merupakan hal yang asing di Indonesia. Tempat makan-makan bertema Jepang, Cina atau Korea biasanya selalu menyediakan sumpit bagi anda. Anda harus biasa memengang sumpit dengan benar agar dapat menyantap hidangan dengan nyaman.

4. Pulukan atau menggunakan tangan

Makan dengan menggunakan tangan adalah salah satu cara makan yang wajar di Indonesia, khususnya untuk menyantap makanan- makanan yang tidak berkuah. Makan dengan menggunakan tangan sangatlah mudah. Hal yang perlu diperhatikan adalah usahakan hanya menggunakan bagian ujung dari jari-jari saja saat makan.

b) Aturan Penempatan Alat Makan

Penataan meja makan di hotel dan restoran memiliki standar internasional. Baik jenis alat makan maupun napkin. Ukuran napkin standar jamuan resmi yang disarankan untuk hotel adalah $45 \times 45 \mathrm{~cm}$. Adapun peletakan napkin biasanya diletakkan di atas dinner plate atau piring makan, adakalanya napkin diletakkan di sebelah kiri piring.

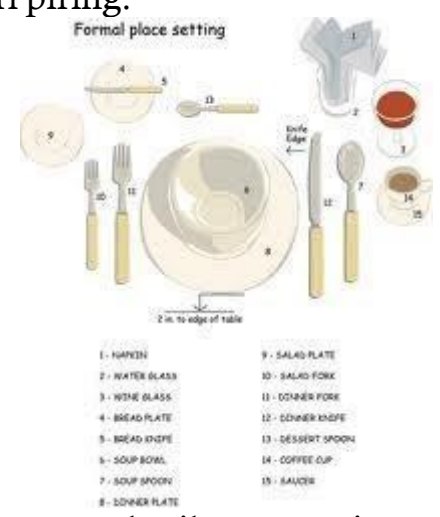

Sesi ketiga. Pada sesi ini pembicara memberikan materi mengenai Etika Makan, sebagai berikut :

Etika di Meja Makan:

1. Posisi duduk, usahakan jarak antara badan Anda dengan tepi meja sekitar $10-15$ $\mathrm{cm}$. Dalam jarak ini Anda dapat menikmati hidangan dengan posisi nyaman.

2. Biasakan duduk dengan posisi punggung tegak dan selalu meletakkan posisi tangan di atas meja sebatas pergelangan tangan, jangan meletakkan siku di atas meja.

3. Barang bawaan tidak boleh diletakkan di atas meja.

Kompetensi

Komunikasi Bisnis

Bagi Karyawan 
Kompetensi

Komunikasi Bisnis

Bagi Karyawan

72

\section{JADKES}

Jurnal Abdimas Dedikasi Kesatuan

Vol. 1 No. 1, 2020 pp. $67-76$

IBI KESATUAN

E-ISSN XXXX - XXXX

DOI:
4. Kaki tidak boleh ditumpangkan satu sama lainnya selama jamuan berlangsung.

5. Jika ingin bersin/batuk, palingkan muka kesamping agak kebelakang dan tutupi dengan napkin. Lalu ucapkan kata "maafkan saya".

6. Jika ingin menerima telpon, lihat dahulu siapa yang menelpon. Jika teman, sebaiknya tidak diangkat. Sebaliknya jika yang menelpon adalah atasan, sebaiknya Anda meminta izin kebelakang lalu menelpon kembali.

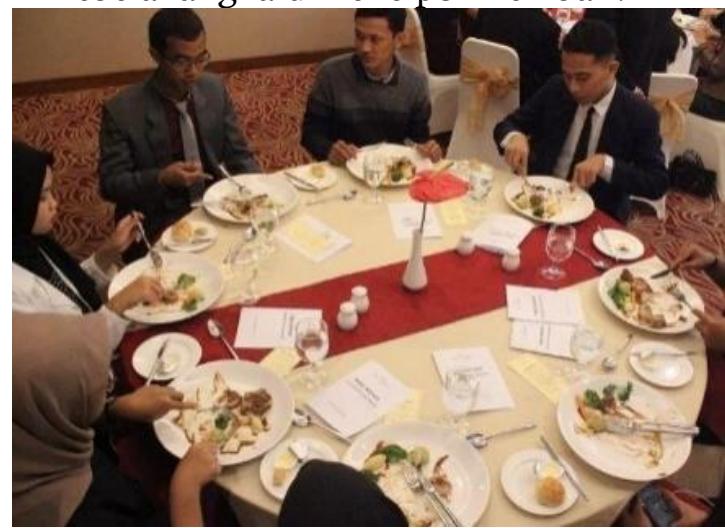

Cara Menggunakan Alat Makan

1. Dinner napkin (serbet makan) diletakkan di atas pangkuan dan apabila telah selesai makan atau meninggalkan tempat, napkin dilipat dan ditaruh di atas meja.

2. Napkin dilipat dan diletakkan dikursi Anda bila hendak meninggalkan tempat untuk pergi ke toilet.

3. Napkin tidak digunakan untuk lipstik atau peralatan makan yang kotor.

4. Peralatan makan yang akan digunakan paling awal adalah peralatan makan yang diletakkan pada bagian yang paling luar dari tatanan yang ada.

5. Apabila ada peralatan makan yang terjatuh, segera mengacungkan tangan dan petugas akan mengambilnya dan menggantinya dengan yang baru.

6. Cangkir kopi/teh ada disebelah kanan dan dapat dipindahkan ke tengah bila sudah selesai makan dan diisi teh/kopi.

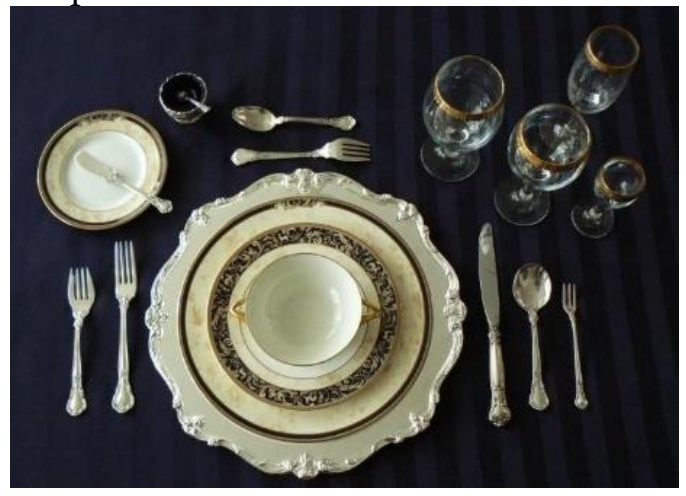

Tata Cara Makan

1. Makanlah hidangan yang sesuai dengan urutan menunya.

2. Mulut sebaiknya tertutup sewaktu mengunyah untuk menghindari suara yang dapat mengganggu.

3. Memotong makanan jangan sampai terlalu besar karena dapat mengganggu pada waktu menguyah, jadi sesuaikan dengan kemampuan mulut yang wajar untuk dimakan.

4. Tidak berdahak selama jamuan makan berlangsung.

5. Jangan berbicara selagi mengunyah makanan.

6. Jangan berkumur dengan air minum sewaktu masih brada di meja makan.

7. Mengaduk gula pada cangkir kopi/teh jangan sampai menimbulkan suara keras. Sendok teh/kopi hanya digunakan untuk mengaduk saja.

8. Jika menyendok sup, usahakan dari depan ke belakang. Tangan kiri memegang kuping mangkuk. 
9. Jika sup tinggal sedikit dan sulit disendok, miringkan mangkuk ke arah depan.

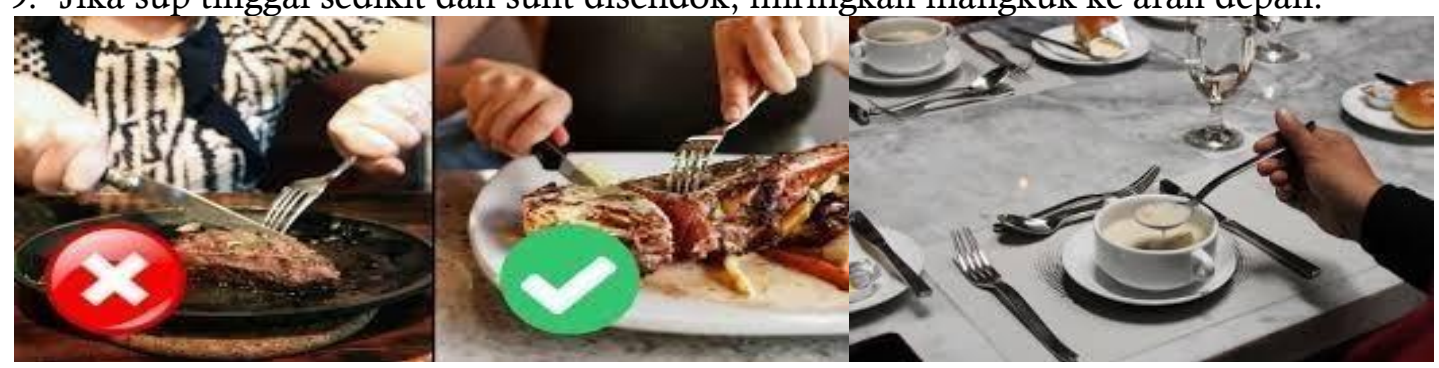

Etika Makan Internasional

1. Hidangan pembuka (Appetizer). Sebelum hidangan pembuka disajikan pada BAB plate (Brean And Butter) sudah disajikan roti dan mentega, biasanya dinner roll, soft roll atau brioche. Roti ini disantap dengan mentega sambil menunggu hidangan pembuka tiba, jangan menyantapnya dengan menggunakan pisau dan garpu.

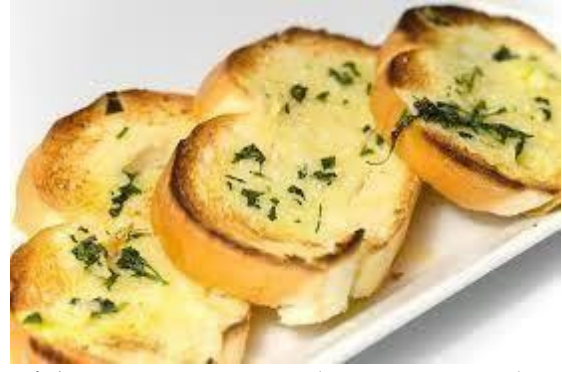

2. Hidangan Utama (Main Course). Hidangan utama biasanya berupa hidangan dari daging, unggas, sea food maupun telur. Baik dilengkapi saus maupun tidak. Ada kalanya main course disajikan bersam sayuran dan kentang sebagai pendamping menu utama.

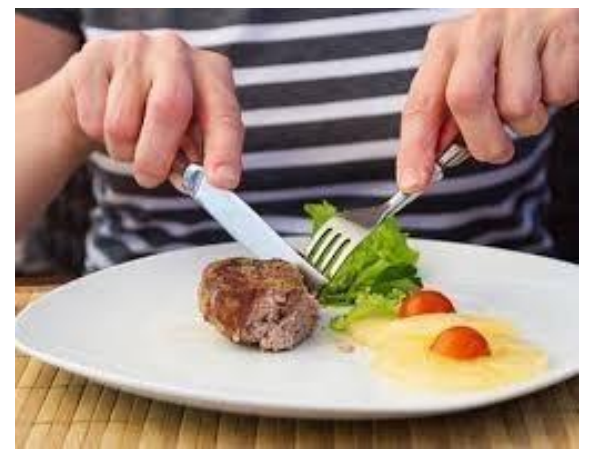

3. Hidangan Penutup (Dessert). Hidangan penutup banyak sekali ragamnya, ada kalanya disajikan aneka cake, ice cream, pudding atau potongan buah- buahan. Alat hiding yang digunakan berupa sendok, garpu dan pisau kecil yang diletakan pada bagian atas piring main course. Jika dessert berupa minuman maka disajikan dalam gelas.

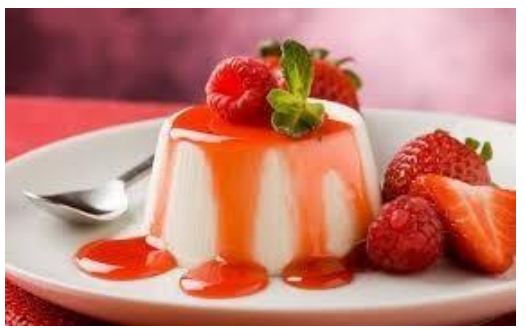

4. Digestif drink. Sering juga disebut after dinner drink, minuman ini dinikmati setela acara jamuan makan selesai. Fungsi dari sajian ini adalah untuk membantu mencerna makanan.

Kompetensi

Komunikasi Bisnis

Bagi Karyawan 
Kompetensi Komunikasi Bisnis Bagi Karyawan

$\underline{74}$

\section{JADKES}

Jurnal Abdimas Dedikasi Kesatuan Vol. 1 No. 1, 2020 pp. $67-76$ IBI KESATUAN E-ISSN XXXX - XXXX DOI:

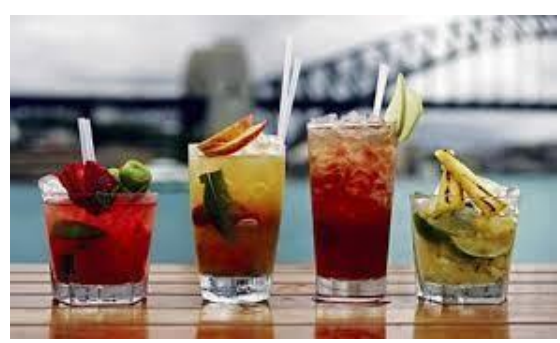

Sesi keempat. Sesi ini merupakan sesi tambahan, dimana pada sesi ini pembicara memberikan materi tentang etika jamuan makan bisnis, yaitu:

a) Memperkenalkan Sesama Kolega. Jika Anda sedang berada diacara makan siang bisnis dan ingin memperkenalkan atasan Anda pada kolega dari perusahaan lain, misalnya, sudah pasti dalam hal ini atasan Anda merupakan orang yang lebih penting. Katakan langsung kepadanya, "Pak, perkenalkan Sdr. Putra dari Perusahaan X." Lalu kepada Putra, katakan, "Putra, perkenalkan atasan saya dari Perusahaan Y, Bapak Pangaribuan". Dengan demikian, perkenalan singkat tadi dapat berkembang pada pembicaraan lebih lanjut diantara mereka. Anda dapat mengganti contoh atasan dan kolega dengan ibu Anda dan teman, atau kakek Anda dengan sahabat Anda. Bila tidak yakin siapa yang harus Anda dahulukan, Anda dapat memilih seseorang yang sepantasnya didahulukan.

b) Berdiri. Jika ada yang bangun menurut etika, seorang pria sebaiknya berdiri jika rekan semejanya yang berjenis kelamin wanita meninggalkan meja atau kembali ke meja setelah ia dari kamar kecil, misalnya. Hal ini tampak kuno tetapi tetap berlaku untuk masa kini. Kecuali pada acara makan siang bisnis, seorang pria harus berdiri bila seorang wanita yang duduk di meja yang sama, apakah itu istrinya atau orang lain, akan meninggalkan meja ataupun kembali ke meja. Terutama bila wanita tersebut duduk di sebelah Anda. Para wanita menghargai sikap ini. Pada meja yang agak padat, beri ruang pada seorang wanita yang akan duduk ataupun berdiri.

c) Perbaiki Dasi. Walaupun Anda sedang merasa sangat lapar dan ingin segera makan, jangan lupa atur letak dasi sebelum mulai menyantap hidangan sehingga tidak mengganggu saat Anda tengah makan. Jangan letakkan dasi ke belakang bahu karena hal ini tampak tidak sopan dan tidak rapi. Bila tidak mempunyai klip khusus untuk dasi, masukkan sedikit bagian ujung dasi ke dalam kemeja. Serbet juga dapat dipakai untuk menutupi dasi Anda.

d) Cicipi. Anda tidak tahu apakah makanan yang akan dimakan sudah cukup asin atau belum. Jangan rusak acara makan tersebut dengan menambahkan garam pada makanan sebelum Anda tahu pasti apakah makanan tersebut sudah cukup asin atau belum bagi Anda. Karena dengan langsung menambahkan garam tanpa mencicipinya terlebih dahulu dan ternyata makanan tersebut sudah cukup asin, Anda tidak mungkin dapat menghabiskan makanan tersebut dan hal ini akan memberi kesan tidak baik. Alasan berikut (dan hanya berlaku dipesta makan malam), menambahkan garam pada makanan di piring Anda akan memberi kesan seakan Anda tidak percaya terhadap masakan tuan rumah. Bila ditanya apakah perlu garam, minta garam dan lada, karena garam dan lada selalu berada bersama.

e) Siku di Meja. Meletakkan siku di meja memang nyaman tetapi hal ini tidak dibenarkan bila Anda melakukannya pada suatu jamuan makan siang atau makan malam. Hal ini memberi kesan tidak sopan. Apalagi bila kemeja yang Anda kenakan berlengan panjang. Bila terkena noda, akan terlihat jelas. Kapan Anda boleh meletakkan siku di meja makan? Waktu yang tepat adalah diantara dua makanan. Maksudnya, pada waktu selesai menyantap makanan pembuka dan akan masuk ke makanan utama atau pada saat selesai menyantap makanan utama dan akan melahap makanan penutup. Anda dapat relaks sebentar sambil menantikan makanan berikutnya. Atau dapat juga pada saat Anda harus berbicara dengan teman satu meja yang posisinya tak langsung di sebelah Anda. Letakkan siku di atas serbet dan dekatkan posisi Anda dengan lawan bicara sehingga Anda dapat mendengar apa 
yang dikatakannya.

\section{Evaluasi Hasil Kegiatan}

Evaluasi proses pelatihan dilakukan dengan tanya jawab dan praktek serta pengamatan selama proses pelatihan diselenggarakan. Indikator keberhasilan selama proses pelatihan dilakukan, tim Lembaga Penelitian dan Pengembangan (LPPM) STIE Kesatuan melakukan penilaian terhadap keterlibatan dan kemampuan peserta pada setiap tahap pelatihan. Peserta cukup antusias dalam mengikuti acara tersebut, hal ini ditunjukkan dengan intensitas pertanyaan yang diajukan atas materi yang disampaikan.

\section{Pembahasan}

Kegiatan program Pengabdian kepada Masyarakat yang diselenggarakan oleh Lembaga Penelitian dan Pengabdian pada Masyarakat (LPPM) STIE Kesatuan ini telah terselenggara dengan baik dan lancar. Secara umum karyawan BPR MANDIRI memberikan respon positif atas pelaksanaan kegiatan ini. Para peserta mengharapkan kegiatan ini dapat diselenggarakan kembali dengan topik yang lebih beragam sehingga dapat memberikan pemahaman mengenai etika makan yang baik dan benar bukan hanya secara internasional tetapi sesuai dengan ragam adat istiadat yang ada di Indonesia. Dengan terselenggaranya kegiatan pelatihan Table manners bagi BPR MANDIRI di wilayah kota Bogor diharapkan karyawan BPR MANDIRI memahami aturan yang harus dilakukan saat bersantap bersama di meja makan. Sehingga jika mampu menunjukkan sopan santun di meja makan, akan menunjukkan kualitas pergaulan, intelektualitas dan etika pergaulan seseorang. Dengan jamuan makan yang baik, diharapkan pengusaha mampu mendapatkan relasi bisnis yang baru sehingga bisnis yang dijalankan diharapkan akan terus berkembang dan mampu bersaing dengan baik.

\section{PENUTUP}

\section{Kesimpulan}

Pelaksanaan kegiatan Pengabdian kepada Masyarakat berupa pelatihan Table manners bagi BPR MANDIRI telah dilaksanakan dengan baik. Indikator kepuasan atas pelatihan tersebut antara lain :

1. Respon yang ditunjukkan oleh peserta selama kegiatan berlangsung. Respon tersebut berupa intensitas pertanyaan serta tanggapan yang diberikan secara langsung oleh pembicara dalam merespon pertanyaan yang diajukan. Kualitas jawaban yang disampaikan dapat memuaskan peserta sehingga terlihat peserta memperoleh pemahaman yang lebih baik dibandingkan sebelum melakukan pelatihan ini.

2. Kesesuaian antara materi dengan kebutuhan karyawan BPR MANDIRI demi terciptanya kualitas SDM yang lebih percaya diri dengan semangat kewirausahaan yang tinggi, termotivasi untuk mengembangkan usaha ke arah yang lebih maju sehingga diharapkan karyawan BPR MANDIRI dapat tumbuh dan berkembang serta mampu bersaing secara mandiri dalam mengelola bisnis yang dijalankan. Sehingga dengan kondisi tersebut akan meningkatkan pertumbuhan perekonomian di wilayah Bogor.

3. Peserta memahami aturan yang harus dilakukan saat bersantap bersama di meja makan. Sehingga jika mampu menunjukkan sopan santun di meja makan, akan menunjukkan kualitas pergaulan, intelektualitas dan etika pergaulan seseorang.

4. Dengan jamuan makan yang baik, diharapkan pengusaha mampu mendapatkan relasi bisnis yang baru sehingga bisnis yang dijalankan diharapkan akan terus berkembang dan mampu bersaing dengan baik.

5. Kegiatan pengabdian kepada masyarakat ini dapat dijadikan sharing pengetahuan konseptual hingga implementasi bagi pemateri dan peserta. Sehingga menjadi sarana transfer knowledge yang dilakukan antara pembicara yang berlatar belakang akademisi dan praktisi dengan karyawan BPR Mandiri.
Kompetensi

Komunikasi Bisnis

Bagi Karyawan



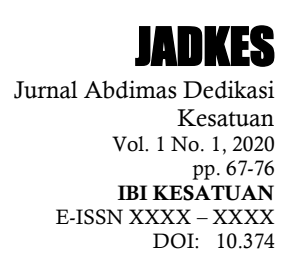


Kompetensi

Komunikasi Bisnis

Bagi Karyawan

\section{6}

\section{JADKES}

Jurnal Abdimas Dedikasi

Kesatuan

Vol. 1 No. 1, 2020

pp. $67-76$

IBI KESATUAN

E-ISSN XXXX - XXXX DOI:

\section{Rekomendasi}

Rekomendasi yang dapat diberikan sehubungan dengan penyelenggaraan kegiatan pelatihan Table manners bagi BPR MANDIRI dapat dijelaskan sebagai berikut :

1. Karyawan BPR MANDIRI yang mengikuti pelatihan diharapkan memahami aturan yang harus dilakukan saat bersantap bersama di meja makan. Sehingga jika mampu menunjukkan sopan santun di meja makan, akan menunjukkan kualitas pergaulan, intelektualitas dan etika pergaulan seseorang.

2. Dengan jamuan makan yang baik, diharapkan pengusaha mampu mendapatkan relasi bisnis yang baru sehingga bisnis yang dijalankan diharapkan akan terus berkembang dan mampu bersaing dengan baik.

3. Pelatihan yang diselenggarakan bagi BPR MANDIRI sebaiknya dapat diselenggarakan kembali dengan topik yang lebih beragam sehingga dapat memberikan pemahaman mengenai etika makan yang baik dan benar bukan hanya secara internasional tetapi sesuai dengan ragam adat istiadat yang ada di Indonesia.

\section{DAFTAR PUSTAKA}

Arkandas. 2012. Tips Table Manner Paling Lengkap.Tersedia: http://www.masarkandas.blogspot.com/2012/06/tips-table-manner-palinglengkap.html

I.N.R. Pendit. 2004. Table Manner Dinning Etiquette dan Etiket Dalam Jamuan. Penerbit: Graha Ilmu

Munadjat, Arief. 2009. Etiket Jamuan Makan Internasional Table. Tersedia: http://warnapelangidunia.blogspot.com/2009/09/etiket-jamuan-makaninternasionaltable.html

Dewi, E.T. and Srihandoko, W., 2018. Pengaruh Risiko Kredit dan Risiko Likuiditas Terhadap Profitabilitas Bank. Jurnal Ilmiah Manajemen Kesatuan, 6(3), pp.131-138.

Cahyani, N., Harni, B. and Suparman, S., 2018. Analisis Kesenjangan Kompetensi Dan Harapan Pengguna Lulusan Perbankan. JAS-PT (Jurnal Analisis Sistem Pendidikan Tinggi Indonesia), 1(2), pp.103-113.

Iriyadi, I., Maulana, M.A. and Nurjanah, Y., 2018, December. Financial Reporting for Micro Small and Medium Enterprises Towards Industrial Revolution Era 4.0. In International Conference On Accounting And Management Science 2018 (pp. 32-38).

JK, A.E., Nurjanah, Y. and Munawar, A., 2019. Peranan Sistem Informasi Akuntansi Piutang Terhadap Pengendalian Piutang (Studi Kasus Pada Pt. Arwinda Perwira Utama). Jurnal Ilmiah Manajemen Kesatuan, 7(1), pp.192-172.

Keren, K. and Sulistiono, S., 2019. Pengaruh Motivasi, Budaya, dan Sikap Konsumen Terhadap Keputusan Pembelian Produk Indomie. Jurnal Ilmiah Manajemen Kesatuan, 7(3), pp.319-324.

Manurung, T.M.S., 2017. Pengaruh motivasi dan perilaku belajar terhadap prestasi akademik mahasiswa. JAS-PT (Jurnal Analisis Sistem Pendidikan Tinggi Indonesia), 1(1), pp.17-26.

Mashadi, M., Nurachmad, E. and Mulyana, M., 2019. Analisis Deskriptif Penilaian Website Perguruan Tinggi. JAS-PT (Jurnal Analisis Sistem Pendidikan Tinggi Indonesia), 3(2), pp.97-106.

Purba, J.H.V. and Septian, M.R., 2019. Analysis of Short Term Financial Performance: A Case Study of an Energy Service Provider. Journal of Accounting Research, Organization and Economics, 2(2), pp.113-122.

Sulistiono, S., Nurendah, Y. and Mulyana, M., 2019. Mengukur Minat Studi Siswa SMA dan SMK di Kota Bogor Pada Program Studi Kewirausahaan. JAS-PT (Jurnal Analisis Sistem Pendidikan Tinggi Indonesia), 3(1), pp.1-12.

Wiratama, A., Muktiadji, N. and Cahyani, N., 2019. Asset Management, Pt Taisho Pharmaceutical Tbk. Jurnal Ilmiah Manajemen Kesatuan, 7(1), pp.145-152 